\title{
PARADIPLOMASI MELALUI KERJASAMA SISTERCITY: UPAYA UNTUK MENINGKATKAN POTENSI INDUSTRI PARIWISATA DI KABUPATEN SUMENEP
}

\author{
Oleh: \\ Alia Rizka Mansyur \\ Fakultas Ilmu Sosial dan Ilmu Politik, Universitas Muhammadiyah Malang \\ Email: aliarizka192@gmail.com
}

\begin{abstract}
Abstrak
Penelitian ini bertujuan untuk meningkatakan upaya potensi pariwisata di kabupaten Sumenep dengan menggunakan konsep paradiplomasi Kerjasama sister city sebagai salah satu upaya inovasi pemerintah daerah dalam memberikan kesejahteraan dan ekonomi masyarakat. Sejalan dengan proses globalisasi, para actor hubungan internasional juga meluas tidak hanya melingkup negara (state actor) saja tetapi meluas pada actor-aktor selain negara (non-state actor) seperti organisasi internasional, LSM, MNCs, media, daerah, kelompok-kelompok minoritas, bahkan individu. Dari hal tersebut kita meihat bahwa beragam actor yang terlibat dalam hubungan dan kerja sama luar negeri semakin kompleks terutama dalam proses pengambilan keputusan. Mmetode penelitan, peneliti menggunakan metode studi literatur. Studi literatur yaitu peneliti menaalah secara tekun akan kepustakaan yang diperlukan dalam penelitian. Banyaknya potensi industri pariwisata di kabupaten Sumenep belum optimal, upaya pemerintah kabupaten Sumenep menggunakan Kerjasama sister city merupakan salah satu solusi untuk meingkatakan parawisatawan local dan asing.
\end{abstract}

Kata Kunci: Paradiplomasi, Sister City, Pariwisata, Sumenep.

\section{PENDAHULUAN}

Pulau Madura merupakan sebuah pulau yang menyimpan banyak potensi industri pariwisata. Namun pada kenyataannya sampai saat ini objek wisata yang berada di Pulau Madura belum bisa menarik banyak wisatawan. Kabupaten sumenep merupakan salah satu kabupaten yang berada di pulau madura yang memiliki potensi sumberdaya pariwisata yang dominan terutama sumberdaya pesisir dan lautan. Sumenep terkenal dengan kekayaan dan keanekaragaman sumberdaya alamnya terlepas dari keanekaragaman budaya dan religi. Salah satu sumberdaya alam yang di miliki oleh sumenep adalah sumberdaya perikanan laut, mangrove, terumbu karang, padang lamun, rumput laut, dan bahan-bahan bioaktif, minyak bumi, gas, mineral, pasir, dan bahan tambang lainnya) serta berbagai macam energi kelautan (gelombang, pasang surut, dan angin.

Salah satu fenomena langka yang bisa kita lihat di Kabupaten sumenep adalah adanya pohon cemara. Meskipun Padahal cemara biasa tumbuh di daerah pegunungan, namun dikabupaten sumenep ada pohon cemara yang tumbuh di pesisir pantai Lombang yang disebut cemara udang dan pohon ini biasa ditemukan di Tiongkok. Dinamakan demikian 
disebabakan bentuknya tidak meruncing ke atas, tapi bungkuk dan mirip seperti capit udang. Ini yang membuat warga lokal menamakannya cemara udang. (Kompas.com, 2019) Kemudian tepatnya di pulau Giliyang, salah satu pulau yang dimiliki oleh Sumenep disebut sebagai pulau yang memiliki kadar oksigen terbaik kedua didunia setelah Yordania, disebabkan kadar oksigen yang tinggi mengakibatkan Kesehatan penduduk di pulau Giliyang memiliki rata-rata usia panjang hingga mencapai usia lebih 100 tahun. (Kurniawan, 2016). Selanjutnya, pantai berpasir putih yang bercampur dengan pasir hitam juga berada di sumenep madura terletak di pantai Slopeng. Tidak hanya warna pasir yang berbeda dari biasanya tetapi juga terdapat bukit-bukit pasir yang menjulang hingga 3 meter. Bukit pasir tersebut hampir menyerupai dataran tinggi, terlebih karena banyak pohon yang memenuhinya. Gunung pasir di Pantai Slopeng ini ibarat pagar yang memisahkan keindahan pantai dengan jalan besar. (Astarini, 2018) Pesona Pulau Gili Labak sebuah pulau kecil di Sumenep, pesonanya menawarkan keindahan yang menarik bagi wisatawan. Kondisi pantai masih alami, bentangan pasir putih, serta lautan biru yang jernih yang disebut tak kalah indah dengan Gili Trawangan yang berada di Nusa Tenggara Barat. (Josiand, 2015)
Sumenep memiliki kekayaan budaya yang ikonik salah satunya ialah keris. Hal tersebut juga mendasari kabupaten ujung timur Madura ini mendapat julukan Kota Keris. Berdasarkan catatan UNESCO, empu keris terbanyak di Indonesia berada di Sumenep dimana terdapat sekitar 652 empu yang terdata pada tahun 2018. (Basri, 2019) Potensi sumberdaya kelautan di sumenep, salah satunya berada di kecamatan Sapeken yang berada di pulau Kangean adalah jenis ikan pelagis (permukaan) dan ikan demersal (karang) seperti ikan kerapu dan kakap merah. Ikan kerapu sendiri cukup menjanjikan bagi masyarakat Keuntungan yang diperoleh dari hasil tangkap ikan sangat besar. Bahkan, satu ekor ikan kakap merah dengan berat lebih satu kilogram bisa dihargai $\quad R p \quad 1$ juta. (radarmadura.jawapos.com, 2019) potensi berikutnya ialah menjadi destinasi wisata halal dengan didukung berbagai objek wisata dan fasilitas. Potensi berikutnya ialah potensi pengelolaan laut yang besar didikung dengan posisi daerah Sumenep sendiri. Selain kondisi perairan yang masih bagus daerah pantainya memeiliki substrat yang cocok untuk budidaya seperti, budidaya rumput laut, ikan, udang. Budidaya yang perlu dikembangkan adalah rumput laut. Selain Sumenep sudah dikenal diluar daerah Sumenep juga dikenal sebagai penghasil rumput laut 
terbesar di Propinsi Jawa timur dengan kualitas bagus. (Syah \& Efendy, 2011)

Kabupaten Sumenep memiliki potensi yang besar untuk menjadi destinasi wisata halal, hal ini didukung oleh tersedianya objek-objek wisata dan fasilitas serta dukungan dari pemerintah untuk mengembangkan wisata halal di kabupaten Sumenep. Potensi yang besar ini perlu diimbangi dengan manajemen yang handal untuk menjadikan Sumenep menjadi destinasi wisata halal. Menyusun dan merangkum sebuah panduan untuk aplikasi wisata Syariah, beberapa panduan Destinasi Wisata Syariah ialah Destinasi wisata yang meliputi wisata alam, budaya dan buatan, Fasilitas ibadah yang layak dan suci, pertunjukan seni dan budaya serta atraksi yang tidak bertentangan dengan ketentuan pariwisata Syariah, tersedia makanan dan minuman halal, dan Kebersihan sanitasi dan lingkungan yang terjaga. (Kurniawan, et al., 2018)

Kabupaten Sumenep secara garis besar di bagi menjadi dua bagian yaitu daratan dan kepulauan. Adapaun di bagian daratan yang menjadi pusat perhatian adalah kecamatan-kecamatan yang berhubungan langsung dengan laut yaitu terdapat 11 kecamatan yang kemudian bisa dibagi menjadi kecamatan sisi bagian selatan dan bagian utara. Kecamatankecamatan yang terletak di sebelah utara yaitu Kecamatan Pasongsongan,
Kecamatan Ambunten, Kecamatan Dasuk, Kecamatan Batu Putih, dan Kecamatan Batangbatang. Sedangkan sisi bagian selatan terdiri dari Kecamatan Pragaan, Kecamatan Bluto, Kecamatan Saronggi, Kecamatan Kalianget, Kecamatan Gapura, dan Kecamatan Dungkek. Kabupaten Sumenep memiliki 19 Kecamatan yang terdapat sumberdaya pesisir dan lautnya. Sebelas kecamatan ada ada di pulau Madura dan 8 kecamatan lainnya terdapat di kepulauan Sumenep. (Syah \& Efendy, 2011)

Kemajuan teknologi komunikasi telah mendorong globalisasi saling ketergantungan antar negara dan antar masalah semakin erat. Akibatnya tercipta suatu dunia tanpa batas (borderless world) yang seolah-olah telah membentuk suatu global village bagi masyarakat dunia, yang mengakibatkan perubahan-perubahan mendasar yang terjadi di lingkup nasional, regional maupun global, dan telah menuntut kebijakan dan perangkat baru dalam pelaksanaan hubungan antar negara. (PERATURAN MENTERI LUAR NEGERI REPUBLIK INDONESIA NO.09/A/KP/XII/2006/01) Pariwisata di daerah harusnya mampu memanfaatkan dan menjaga potensi-potensi yang ada, pemerintah dan masyarakat daerah saling membantu dalam pengembangannya tersebut sehingga berdampak dalam peningkatan segi ekonomi, budaya dan 
pendidikan daerah tersebut. Pariwisata sangatlah mampu dalam mengatasi masalah kesejahteraan bila dikembangkan secara baik dan profesional.

Sejalan dengan proses globalisasi, para actor hubungan internasional juga meluas tidak hanya melingkup negara (state actor) saja tetapi meluas pada actoraktor selain negara (non-state actor) seperti organisasi internasional, LSM, MNCs, media, daerah, kelompokkelompok minoritas, bahkan individu. Dari hal tersebut kita meihat bahwa beragam actor yang terlibat dalam hubungan dan kerja sama luar negeri semakin kompleks terutama dalam proses pengambilan keputusan. (Thontowi, 2009)

Jika kita melihat ke dalam unit analisis negara, bukan lagi hanya pemerintah pusat yang memiliki wewenang dalam menjalin hubungan kerjasama internasional. Hal ini bertujuan untuk mencapai kepentingan nasional secara khusus sesuai dengan pemenuhan kebutuhan masyarakat per-wilayah di suatu negara yang tidak dapat dipenuhi secara mandiri. Maka dari itu, terdapat penyerahan sebagian wewenang pemerintah pusat dalam menjalin kerjasama internasional kepada pemerintah daerah. Tertuang dalam Undang-Undang Nomor 32 Tahun 2004 tentang Pemerintahan Daerah yang mengisyaratkan perlu dilakukannya penyesuaian kewenangan pelaksanaan hubungan dan kerjasama luar negeri yang sebelumnya diatur dalam Undang-Undang No. 22 Tahun 1999 Tentang Pemerintahan Daerah. (Thontowi, 2009) Adapum pelaksanaan politik luar negeri merupakan kewenangan dari pemerintah pusat, maun seiring dengan berkembangnya undangundang otonomi daerah, kebijakan hubungan luar negeri dan diplomasi oleh pemerintah pusat antara lain juga diarahkan untuk memberdayakan dan mempromosikan potensi daerah. Perubahan paradigma kerjasama luar negeri melalui undang-undang otonomi daerah tersebut, maka pemerintah daerah akhir-akhir ini dengan leluasa membuka akses kerjasama dengan pemerintah daerah yang ada di luar negeri, baik melalui kerjasama sister city/province, dan lain sebagainya.

Dalam hal ini untuk meningkatkan potensi industri pariwisata di Sumenep ialah dengan memanfaatkan model kerjasama sister city atau kota kembar. Model sister city sendiri mulai berkembang pesat sejak tahun 1980an namun di Indoensia baru digunakan secara formal pada tahun 1993. Model kerjasama sister city dapat dijadikan instrumen bagi sebuah kota yang memiliki kesamaan karakteristik dengan tujuan untuk meningkatkan hubungan antar dua daerah. (Sunarko \& Yuniati, 2017) 
Kolaborasi promosi industri pariwisata dengan kerjasama sinergis menggunakan konsep sister city, dalam pelaksanaannya tentu saja akan melibatkan dua entitas yang berbeda. Karenanya, penyatuan atau lebih tepatnya intensi kuat untuk melakukan harmonisasi visi dan misi antara kedua pemerintah daerah dan upaya membangkitkan partisipasi aktif di kalangan masyarakat menjadi prasyarat penting bagi kesuksesan program kerjasama sister city. Hal ini mengingat masih terdapat kerjasama sister city yang telah dilakukan oleh beberapa pemerintah daerah justru berujung pada tidak optimalnya pencapaian tujuan kerjasama atau bahkan mengalami kegagalan. Oleh karena itu persiapan matang menjadi perhatian penting bagi bagi pemerintah daerah yang hendak menjalin kerjasama sister city. Mengacu pada uraian di atas maka tulisan ini ingin mengkaji tentang bagaimana upaya untuk meningkatkan potensi industri pariwisata di kabupaten Sumenep menggunakan konsep Kerjasama sister city?

\section{TINJAUAN TEORITIS}

Konsep Paradiplomasi

Paradiplomasi merupakan sebuah fenomena baru dalam kajian hubungan internasional. Pertama kali istilah paradiplomasi digunakan oleh Panayotis pada tahun 1980-an yang merupakan gabungan dari kata parallel Diplomacy. (Wulansari, 1990) Konsep paradiplomasi kemudian menjadi pendekata yang sering digunakan untuk menjelaskan masalah hubungan internasional oleh actor daerah. Duchaek menjelaskan Pardiplomasi memiliki tiga tipe yaitu:

a. Transholder

Paradiplomacy merujuk pada hubungan institusional, formal maupun informal oleh pemerintah daerah yang berbeda negara namun berbatasan langsung secara geografis.

b. Transregional Paradiplomacy yaitu hubungan diplomasi yang dilakukan pemerintah daerah yang berbeda negara dan tidak berbatasan langsung, namun negara dimana kedua pemerintahan tersebut berada berbatasan langsung dalam satu kawasan.

c. Global Paradiplomacy yaitu hubungan diplomasi yang dilakukan pemerintah daerah yang berbeda negara, dari kawasan yang berbeda, dari berbagai belahan dunia (Criekemans, 2008)

Dalam Paradiplomasi di Indonesia memiliki ruang yuridis yang cukup leluasa disebabakan dalam Undang-Undang Nomor 24 Tahun 2000 tentang Perjanjian Internasional dan Undang-Undang Nomor 32 Tahun 2004 tentang Pemerintahan 
Daerah memberikan kewenangan kepada Pemerintah Daerah baik provinsi maupun kabupaten/kota untuk melakukan hubungan dan kerjasama dengan pihak asing. (Wulansari, 1990)

Konsep Sister City

Kerjasama Sister City terbentuk karena adanya persamaan kedudukan dan status administrasi, persamaan ukuran luas wilayah dan fungsi, persamaan karakteristik sosio-kultural dan topografi kewilayahan, persamaan permasalahan yang dihadapi, dan komplementaritas antara kedua pihak dengan tujuan untuk membangun hubungan kerjasama dalam pertukaran kunjungan pejabat atau pengusaha, yang nantinya akan menimbulkan kerjasama dalam hubungan barang dan jasa. (Isnaeni, 2013) Program kerjasama Sister City dimaksudkan untuk membangun kerjasama menyeluruh pada tingkat kota, memajukan kebudayaan, serta mendorong perkembangan ekonomi. Dalam hal ini, pelaksanaan konsep sister city bertujuan untuk:

a. Memperkuat kerjasama antar kotakota yang ada di dunia

b. Menyediakan kesempatan bagi para pejabat kota dan masyarakat untuk merasakan dan menjelajahi kebudayaan lain dalam kerjasama jangka panjang

c. Menciptakan keadaan yang membuat perkembangan ekonomi dan masyarakat dapat diimplementasikan dan diperkuat

d. Merangsang lingkungan yang masyarakatnya berusaha belajar, bekerja dan menyelesaikan masalah-masalah bersama secara kreatif dalam timbal balik budaya, pendidikan, perkotaan, bisnis, profesi, dan pertukaran secara teknik dan proyek-proyek.

e. Mengkolaborasikan organisasiorganisasi di dunia dan yang berbagi tujuan serupa (Wulansari, 1990).

Pada penelitian ini penulis menggunakan konsep paradiplomasi yaitu sister city dikarenakan dapat dianggap untuk menjelaskan segala aspek pembahasan yang diangkat. Dengan menggunakan konsep sister city merupakan salah satu upaya untuk meningkatkan potensi pariwisata di Sumenep. Dalam konsep sister city, pemerintah daerah sebagai actor dalam Kerjasama tersebut, hal ini dikatikan dengan pembahasan yang ada bahwa adanya Kerjasama tersebut pemerintah daerah dilakukan melalui pertimbangan yang matang dengan melihat dari beberapa aspek serta faktor-faktor yang ada sehingga hal tersebut yang menjadi dasar untuk dapat memaksimalkan pemerintah Indonesia terkhusus pemerintah daerah dalam mencapai tujuannya yakni untuk 
meningktakan kesejahteraan ekonomi masyarakat salah satunya dengan upaya meningkatkan industri pariwisata.

\section{METODE PENELITIAN}

Jenis Penelitian

Dalam jenis penelitian ini, penulis menggunakan jenis penelitian adalah pendekatan kualitatif. Pendekatan kualitatif merupakan penelitian yang dilakukan untuk meneliti pada sebuah kondisi obyek alamiah. Peneliti adalah sebuah instrument kunci. Adapun Teknik pengumpulan data dilakukan secara kualitatif dan analisis data bersifat induktif/kualitatif dan hasil penelitian kualitatif lebih menekankan makna dari pada generalisasi. (Sugiyono, 2014) Jenis penelitian termasuk dalam penelitian eksploratif yaitu dilakukan untuk mengetahui dan menjelaskan permasalahan secara umum, baru kemudian peneliti melakukan penelitian. Penelitian eksploratif memiliki masalah yang belum pernah dijejaki dan berusaha untuk menemukan atau mengungkapkan permasalahan yang sedang atau akan dibutuhkan dalam penelitian tersebut. (Bungin, 2011) Kemudian metode penelitan, peneliti menggunakan metode studi literatur. Studi literatur yaitu peneliti menaalah secara tekun akan kepustakaan yang diperlukan dalam penelitian (Nazir, 2014) dan juga mengkombinasikan dengan menggunakan wawancara pada informan yang diperlukan dalam penelitian.

Obyek Penelitian

Obyek penelitian merupakan sasaran ilmiah untuk mendapatkan data dengan tujuan dan kegunaan tertentu suatu hal objective, valid dan reliable tentang suatu hal atau variable tertentu. (Sugiyono, 2014, p. 13) Objek penelitian ini bagaimana studi kepustakaan dapat diimplementasikan kedalam upaya Kerjasama Sister City dalam meningkatkan industry pariwisata di Sumenep.

Jenis dan Sumber Data

Jenis dan sumber data dalam penelitian ini menggunakan studi literatur selain dari mencari sumber data sekunder yang akan mendukung penelitian, akan tetapi juga diperlukan untuk mengetahui akan sampai kemana ilmu yang berhubungan dengan penelitian berkembang, sampai terdapat kesimpulan dan degenarlisasi yang telah pernah dibuat hingga memperoleh situasi yang diperlukan. (Nazir, 2014, p. 79)

Penelitian kualitatif ini, penulis menggunakan sumber data sekunder, data sekunder merupakan data yang tidak langsung diberikan kepada peneliti. (Sugiyono, 2014, p. 163) atau sebuah data yang telah dikumpula oleh lembaga pengumpulan data dan dipublikasikan kepada masyarakat pengguna data. Adapun data sekunder dalam penelitian ini 
diperoleh dalam refrensi melalui studi kepustakan seperti buku-buku, refrensi, jurnal, artikel, dan sumber lainnya yang relevan dengan penelitian.

Metode Pengumpulan Data

Dalam penelitian ini, data penelitian menggunakan penelitian kualitatif dengan metode studi literatur sehingga pengumpulan data dalam penelitian selain berasal dari buku refrensi tetapi juga menggunakan sumber-sumber arteikl, jurnal dan berita. (Nazir, 2014)

Analisis Data

Analisis data yang dilakukan peneliti ialah menggunakan studi literatur dan wawancara, studi literatur dilakukan dengan membaca sumber-sumber kepustakaan dengan tujuan untuk memperoleh data yang diperluka (Nazir, 2014, p. 88) dan (Arikunto, 2013)

\section{HASIL DAN PEMBAHASAN}

1. Paradiplomasi Melalui Kerjasama Sister City

$$
\text { Dalam hubungan }
$$

internasional, konsep paradiplomasi hadir sebagai perkembangan dari diplomasi modern dan menarik untuk diteliti. Secara konseptual dan pelaksanaan, konsep paradiplomasi memberikan tantangan bagi para displin hubungan internasional. Paradiplomasi dapat dikatakan sebagai kemunculan dari kemajuan actor selain negara dalam kapasitan untuk mnegeluarkan kebijakan luar negeri. Actor selain negara yang dimaksud yaitu pemerintah kota/daerah, pemerintah provinsi, federasi dan satuan unit yang diberikan otonomi khusus oleh negara. Secara tradisional prinsipprinsip dasar dari paradiplomasi ini tidak jauh berbeda dengan definisi diplomasi yang berdasarkan pada tiga prinsip dasar, yaitu: diselenggarakan dalam kerangka menjalin hubungan perdamaian, saling mengakui terhadap kedaulatan negaranya masingmasing, menjalin hubungan persahabatan dalam jangka waktu yang lama. (Pluijm, 2007 )

Konsep sister city merupakan salah satu cara yang sering dilakukan oleh [emerintah kota/daerah dalam kegiatan paradiplomasi. Sister merupakan bentuk dari Kerjasama yang disepakati secara resmi dan bersifat jangka panjang di antara dua kota berbeda negara. Permahaman terhadap sister city harus dikarakteristikan sebagai upaya timbal balik antar kota yang bekerjasama dan memberikan keuntungan bersama. Adapaun 
karakteristik yang dapat diidentifikasikan sebagai sebuah sister city terbagi kedalam tiga struktur yaitu:

1. Associate dimana mengarahkan pada gagasan dari "international friendship", pertukaran budaya dan kepedulian terhadap isu-isu iternasional secara menyeluruh.

2. Reciproactive yaitu mengembangkan system pertukaran di bidang Pendidikan.

3. Commercial sebagai upaya untuk mengambil keuntungan dari kedua proses (Associative dan Reciproactive) untuk kepentingan peningkatan ekonomi local. (Alam \& Sudirman, 2020)

Tujuan akhir dari skema sister city adalah bagaimana kemudian kedua kota bekerjsama dan mengambil keuntungan bersama. Jika merujuk pada argument diatas maka pada prinsipnya pemerintah Kabupaten Sumenep memilki kemampuan Commercial dalam jaringan internasional dengan membuka luas dengan industry pariwisatanya dan dapat mendapatkan dampak positif dari kegiatan sister city.
Melihat keunggulan yang didapatkan dengan melakukan Kerjasama sister city, perlu kita ketahui bahwa terdapat kelemahannya yaitu; terdapat ketidakpedulian masyarakat atau apatis terhadap hubungan sister city, proses pemilihan kota yang akan dijadikan partner tidak melibatkan masyarakat dan cenderung bersifat "strange choice", ketiga, skema sister city ini sering dijadikan media bagi para politis untuk melakukan perjalanan keluar negeri dengan bersenang-senang, dimana kegiatan tersebut di biayai oleh pemerintah local dengan menggunakan sumber dana uang pajak masyarakat. (Alam \& Sudirman, 2020)

Walaupun demikian, kesadaran akan pentingnya paradiplomasi yang dilakukan oleh pemerintah kota/daerah dalam upaya untuk meningkatkan kesejahteraan dan pembangunan ekonomi serta untuk mempromosikan kebudayaan dan sosial untuk memperdayakan masyarakat diperkotaan menjadikan paradiplomasi sebagai salah satu peran strategis yang dapat dilakukan oleh oleh pemerintah kota/daerah. Oleh 
sebab itu, perlunya penguatan kemampuan, kapabilitas dan kapasitas perlaku paradiplomasi. Hanya dengan sumber daya manusia yang memilki kemampuan untuk melaksanakan paradiplomasi oleh kota/daerah sehingga pelaksaan paradiplomasi tidak hanya seremonial belaka.

2. Potensi Wisata di Kabupaten Sumenep

\section{Kabupaten}

Sumenep merupakan salah satu dari empat kabupaten yang berada di Pulau madura, Provinsi Jawa Timur selain Kabupaten Bangkalan, Kabupaten Sampang, dan Kabupaten Pamekasan. Kabupaten Sumenep berada di ujung pulau. Kabupaten sumenep sendiri terbagi menjadi 27 kecamatan, 328 Desa dan \$ kelurahan. Dan terdapat 126 Pulau, 48 pulau berpenghuni dan 78 pulau tak berpenghuni di kabupaten Sumenep. (Fitroni \& Primayud, 2013) Dengan demikian dapat dipastikan Kabupaten Sumenep salah satu daerah yang memiliki banyak objek wisata dan memberikan potensi yang besar untuk dikembangkan sebagai objek pariwisata nasional maupun internasional.
Hal ini dapat membrikan dampak dan kontribusi besar terhadap pembangunan ekonomi di wilayah sekitar, dimana kehadiran pariwisatawan local dan asing mmberikan pendapatan suatu daerah melalui bentuk devisa, pajak maupun retribusi lainnya. Hal tersebut juga berdampak pada peningkatan pembangunanpembangunan industri wisata baru yang berhubungan dengan pariwisata dan meningkatkan lapangan pekerjaan bagi penduduk wilayah Kabupaten Sumenep, sekaligus branding souvenir yang dimiliki oleh Sumenep. Beberapa Objek Wisata yang dimilki oleh Sumenep antara lain:

1. Wisata Kuliner

Berdasarkan data resmi dinas Kebudayaan Pariwisata Pemuda dan Olahraga Kabupaten Sumenep memiliki beberapa makanan khas yang dapat dikunjungi yaitu: Rujak Petis Madura, Sate Gulai, Kaldu Kokot, Soto Sabrang, Keripik SIngkong, Maco, Rengginang, Getthas, Apen dan Patthola.

2. Wisata Alam

Selain wisata kuliner, Kabupaten Sumenep memiliki 
wisata alam yang tidak kalah bagus, (Kurniawan, et al., 2018) yaitu: Pantai Lombang, Pantai Slopeng, Pantai Badur, Goa Payudan, Wisata Batu Kapur Putih.

3. Wisata Kepulauan

Sebagaimana dijelaskan Kabupaten Sumenep memiliki banyak pulau-pulau kecil yang dapat dijadikan objek wisata. (Kurniawan, et al., 2018)

a. Pulau Gili Iyang yang disebut sebagai pulau oksigen terbaik dan terletak di Kecamatan Dungkek.

b. Pulau Gili Labak yang memiliki wisata terumbu karang yang bagus .

c. Pulau Gili Genting yang memilki keunikan pasir yang membentuk angka Sembilan.

d. Pulau Mamburit.

e. Pulau Sapeken memilki keindahan terumbu karang, potensi perikanan, dan gunung pasir yang unik.

f. Pulau Kangen dimana memiliki sekitar 30 buah pulau yang tersebar di Kangen.

g. Pulau Saobi h. Pulau Raas memilki pantai puncak dan wisata bawah laut.

i. Pualu Sepudi memilki wisata yang diunggulkan berupa wisata bahari hujan tropis bawah laut sekaligus pantai pesisir yang didukung dengan komunitas mangrove.

4. Wisata Sejarah

Tidak hanya objek wisata alam dan wisata alam kepulauan yang dimiliki oleh Sumenep, akan tetapi Kabupaten Sumenep juga memilki wisata sejarah. Wisata sejarah tersebut berupa peninggalan sejarah, peralatan dan pusaka yang dapat menjadi objek wisata. Beberapa objek peninggalan sejarah yang dapat menjadi objek industri pariwisata (Kurniawan, et al., 2018) antara lain: Keraton Sumenep, Taman Sare, Kota Tua Kalianget sebagai tempat penghasil garam terbesar di Madura.

5. Wisata Religi.

Kemudian objek wisata lain yaitu wisata religi yang berupa makam raja-raja atau ulama terdahulu. Beberapa objek 
wisata religi yang dapat dikunjungi (Kurniawan, et al., 2018) adalah Masjid Jamik, Asta Tinggi, Asta Katandur, Asta Jokotole, Asta Gumok, Asta Lor Wetan, Asta Yusuf, Asta Kyai Faqih.

6. Wisata Edukasi dan Budaya

Objek wisata lain yang di miliki Sumenep yaitu wisata Esukasi dan Budaya. Seni dan budaya merupakan sebuah karakterisitik dan corak yang dimilki oleh masyarakat Sumenep sebagai salah satu daya Tarik wisatawan local dan asing. Beberapa objek wisata dan edukasi antara lain:

a. Kerajinan Batik di Kecamatan Bluto.

b. Kerajinan Ukiran Topeng di desa Slopeng, Kecamatan Dasuk.

c. Kerajinan Ukiran Kayu di desa Karduluk, Kecamtan Pragaan.

d. Kerajinan Keris di Desa Aeng Tong, Kecamatn Saronggi.

e. Kasur Pasir di desa Legung Kecamatan Batang-batang.

f. Karapa Sapi, Upacara Adat Nyadar, Topeng, Sape' Sono', Ludruk, Musik
Saronen, Musik Tongtong/Musik Daul-daul. (2018).

3. Upaya Kerjasama Sister City Kabupaten Sumenep

Adanya pelaksaan paradiplomasi oleh pemerintah daerah/kota memiliki arti penting yang tidak hanya untuk mengembangkan kesejahteraan dan ekonomi masyarakat daerahnya tetapi juga mendukung diplomasi total yang dilakukan oleh pemerintah pusat bagi pencapaian kepentingan nasional. Apabila paradiplomasi dikelola dengan baik akan memberikan dampak untuk turut eningkatkan kemampuan Indonesia dalam system internasional. Melalui pengelolaan yang baik terhadap paradiplomasi dapat menerapkan kebijakan yang tepat dan mengindari terjadi kekhawatiran dari efek negeatif paradiplomasi, salah satu efek negative paradiplomasi adalah mencari dukungan separatis. Begitupun dengan pemerintahan kota/daerah, apabila tidak mampu memanfaatkan dengan baik, maka akan berdampak pada ketertinggalan kota dari daerah kota lain yang mampu 
memanfaarkan

ppeluan

paradiplomasi.

Dalam hal ini salah satu upaya untuk melakukan kerjsama sister city yaitu melalui persayaratan. Terdapat persyaratan yang harus dipenuhi oleh pemerintah daerah Sumenep yaitu: kesetaraan status administrasi; kesamaan karakteristik; kesamaan permasalahan; upaya saling melengkapi; dan peningkatan hubungan antar masyarakat. Sementara untuk kerja sama yang bersifat teknis, seperti bantuan kemanusiaan, selain persyaratan umum seperti yang telah dikemukakan di atas, maka Pemerintah kota/daerah harus pula memperhatikan persyaratanpersyaratan, seperti peningkatan kemampuan dan keterampilan sumber daya manusia dalam penyelenggaraan pemerintahan kota, kemampuan keuangan kota, prioritas produksi dalam negeri dan kemandirian kota.

Skema kerja sama sister city yang tertuang dalam kajian dari permenlu No: 09/A/KP/XII/2006/01 tentang Panduan Umum Tata Cara Hubungan dan Kerja sama Luar Negeri oleh Pemerintah Daerah dan juga dimasukkan ke dalam UU No. 37 tahun 1999 tentang Hubungan Luar Negeri serta UU No. 32 tahun 2004. Berdasarkan UU no 32 tahun 2004 tentang pemerintah daerah yang didasarkan kepada semangat desentralisasi dan otonomi daerah, aktor sub state seperti kota dan atau kabupaten dapat berperan secara mandiri untuk melakukan kerja sama internasional dengan pihak lain di luar negeri selama tidak berseberangan dengan kepentingan nasional Indonesia. Dalam hal ini, peran kementerian luar negeri lebih bersifat sebagai fasilitator dan leading (Alam \& Sudirman, 2020, p. 38).

Terdapat beberapa syarat
yang harus dipenuhi oleh
pemerintah kota/daerah dalam
upaya untuk melakukan Kerjasama
internasional, (Alam \& Sudirman,
2020, p. 39) yaitu:

1. Kerjasama dengan negara yang memiliki hubungan diplomatic dengan Indonesia.

2. Sesuai dengan bidang kewenangan Pemrintah daerah sebagaimana telah diatur dalam peraturan undang-undang nasional Republik Indonesia.

3. Mendapat persetujuan Dewan Perwakilan Daerah (DPRD). 
4. Tidak mengganggu stabilitas politik dan keamanan dalam negeri.

5. Tidak mengarah pada campur tangan urusan dalam negeri masing-masing negara.

6. Berdasarkan asas persamaan hak dan tidak saling memaksakan kehendak.

7. Memperhatikan prinsip persamaan kedudukan, memberikan manfaat dan menguntungkan bagi pemerintah daerah dan masyarakat.

8. Mendukung penyelenggaraan pemerintahan, pembangunan nasional dan daerah serta pemberdayaan masyarakat.

Upaya untuk melaksanakan sister city ada beberapa prinsip yang dijadikan acuan, meskipun antara satu kota dengan kota lainnya pinsip dapar berbeda-beda. (Nuralam, 2018) Prinsip tersebut adalah Adanya kesamaan atau similaritas, Pertukaran atau potensi pertukaran baik dalam segi budaya, edukasi, hingga ekonomi, hubungan timbal balik, berorientasi pada masyarakat, manfaat strategis, eksklusivitas dan kedekatan, kestabilan politik.
Jika dapat melakukan Kerjasama sister city dengan baik, tentu mendapatkan dampak positif dari Kerjasama sister city tersebut yaitu berkesampatan untuk bertukar pengalaman dan pengetahuan dalam mengelola pembangunan terhadap bidang yang dikerjasamakan, mendorong munculnya ide dan peran aktif pemerintahdaerah kota serta stakeholder lainnya, mempererat persahabatan pemerintah dan masyarakat kedua belah pihak, sebagai kesempatan transfer culture untuk memperkaya kebudayaan daerah. Namun disisi lain skema sister city juga menimbulkan beberapa dampak negatif, diantaranya adalah meningkatnya beban keuangan negara atau daerah karena memakai dana APBN atau APBD, cenderung menunggu fasilitasi dari pemerintah, Memiliki potensi ketidaksetaraan dalam kerja sama yang kurang seimbang sehingga hanya menguntungkan satu pihak (Nuralam, 2018, pp. 146-147)

\section{PENUTUP}

Penelitian untuk mencoba menggambarkan bagaimana Kerjasama sister city apabila dilakukan di kabupaten 
Sumenep. Arti penting dari penelitian ini adalah untuk mengidentifikasi potensial Kerjasama sister city di Kabupaten Sumenep dalam obejk industry Pariwisata. Beberapa hal yang bisa disimpulkan dalam penelitian ini adalah: pertama, sister city adalah salah satu model kerjasama mikro digunakan oleh dua kota di jalur diplomasi bilateral yang berfokus pada peningkatan pembangunan di kedua kota/negara. Dasar dari konsep sister city dilakukan dalam atas dasar kesamaan administrasi, karakteristik sosial-budaya atau geografis atau kesamaan dalam masalah yang dihadapi oleh publik. Dalam era globalisasi saat ini, hubungan antar negara, paradiplomasi akan menjadi salah satu alat dalam mengembangkan potensi lokal dan memecahkan masalah lokal. Kedua, khusus dalam program kerjasama sister city, inisiatif kerjasama ini tidak hanya dapat dilakukan dari kota negara lain, tapi dapat juga dilakukan oleh kota di dalam negeri yang setara. Hal ini dapat dilakukan apabila penjajakan kerjasama sister city mempertimbangkan kepentingan bagi pembangunan dan pengembangan kota secara menyeluruh.

Saran dalam melakukan Kerjasama sister city harus dikemas dengan tujuan jangka panjang dalam mengembangkan Sumber Daya Manusia, Kapasitas pemerintah daerah, masyarakat sehingga dapat memberikan dampak dalam peningkatan kesejahteraan dan ekonomi masyarakat. Dalam hal ini, Pemerintah Sumenep harus berpacu untuk meningkatkan potensi pariwisata yang ada dan wisata yang masih belum dijadikan objek pariwisata, salah satunya melalui paradiplomasi Kerjasama sister city untuk meningkatkan kesejahteraan dan ekonomi masyarakat dengan indsutri pariwisata yang potensial. Berkaitan dengan proses Kerjasama sister city Sumenep dengan actor lain harus sesuai dengan procedural berlaku.

\section{DAFTAR PUSTAKA}

Alam, G. N., \& Sudirman, A. (2020). Paradiplomacy Pemerintah Kota Bandung Melalui Kerja Sama Sister City. Jurnal Ilmiah Hubungan Internasional- PACIS , Vol 16, No. 01, 36-38. doi:https://doi.org/10.26593/jihi.v1 6i1.3365.31-50.

Arikunto, S. (2013). Prosedur Penelitian: Suatu Pendekatan Praktik. Jakarta : Rineka Cipta.

Astarini, D. (2018). Pantai Slopeng, Ikon Wisata Berpasir Unik di Sumenep. Tangerang: merahputih.com.

Basri, A. (2019). Empu Keris Terbanyak di Sumenep Versi UNESCO. 
Sumenep:

radarmadura.jawapos.com.

Retrieved

from

https://radarmadura.jawapos.com/r

ead/2019/09/09/154785/empu-

keris-terbanyak-di-sumenep-versiunesco

Bungin, B. (2011). Metodologi Penelitian

Kualitatif. Jakarta: Rajawali Pers.

Criekemans, D. (2008). Are the

Boundaries

between

Paradiplomacy and Diplomacy

Watering Down? Belgium:

University of Anwerp and Flemish

Centre for International Policy .

Fitroni, A., \& Primayud, K. (2013).

TRAVEL GUIDE BOOK “THE

EPIC JOURNEY OF SUMENEP”.

CREATEVITAS Vol. 2, No. 2, 53-

68.

Isnaeni, N. (2013). Peran Strategis

Pemerintah Daerah dalam Kerja

Sama Internasional untuk

Pembangunan Berkelanjutan.

Global \& Strategis, Th. 7, No. 1, 123-136.

Josiand, A. (2015). Pesona Gili Labak,

'The Hidden Paradise' di Madura.

Sumenep: medcom.id. Retrieved from

https://www.medcom.id/rona/wisat

a-kuliner/zNP2Eq7k-pesona-gili-

labak-the-hidden-paradise-di-

madura
Kompas.com. (2019). Ada Pohon Cemara

Udang di Pantai Lombang. Jakarta:

Kompas.com. Retrieved from

https://pesonaindonesia.kompas.co

$\mathrm{m} / \mathrm{read} / 2019 / 09 / 12 / 160938827 / \mathrm{ada}$

-pohon-cemara-udang-di-pantai-

lombang

Kurniawan, D. (2016). Wow, Pulau Ini Punya Oksigen Terbaik ke-2 di

Dunia. Jakarta: Liputan6.com. Retrieved from https://www.liputan6.com/regional/ read/2555665/wow-pulau-inipunya-oksigen-terbaik-ke-2-didunia

Kurniawan, F., Soeprijanto, A., Guntur, H. L., Wardhana, M., Abadi, I., \& Sayyida. (2018). Pemetaan Potensi Wisata Halal Di Kabupaten Sumenep,Jawa Timur, Indonesia.

Dinar: Jurnal Ekonomi dan Keuangan Islam, 9-10. doi:: https://doi.org/10.21107/dinar

Nazir, M. (2014). Metode Penelitian. Jakarta: Ghalia Indonesia.

Nuralam, I. P. (2018). Peran Strategis Penerapan Konsep Sister City dalam menciptakan Surabaya Green City . Journal of Applied Business Administration Vol 2, No 1, 144-151.

PERATURAN MENTERI LUAR

NEGERI REPUBLIK INDONESIA 
NO.09/A/KP/XII/2006/01. (n.d.).

PANDUAN UMUM TATA CARA

HUBUNGAN DAN KERJASAMA

LUAR NEGERI OLEH

PEMERINTAH DAERAH.

Retrieved from

https://pih.kemlu.go.id/files/Perme

nlu_09-A-KP-XII-2006-01.pdf

Pluijm, R. v. (2007 ). City Diplomacy: The Expanding Role of Cities in International Politics, . Netherlands Institute of International Relations:

Netherlands Institute of International Relations "Clingendael".

radarmadura.jawapos.com. (2019). Satu Kerapu Merah Bisa Seharga Rp 1 Juta, Sapeken Kaya Hasil Laut Kualitas Ekspor. Sumenep: radarmadura.jawapos.com.

Retrieved from https://radarmadura.jawapos.com/r ead/2019/06/10/140579/satu-

kerapu-merah-bisa-seharga-rp-1juta

Sugiyono. (2014). Metode Penelitian Kuantitatif, Kualitatif, dan Kombinasi (Mixed Methods). Bandung: Alfabeta.
Sunarko, B. S., \& Yuniati, S. (2017, Februari 27). Kejasama Sister City: Sebuah Upaya Untuk Meningkatkan Industri Pariwisata di Banyuwangi. Pemberdayaan dan Inovasi Tata Kelola Pemerintahan Daerah dan Desa, pp. 222-223. Retrieved from http://repository.unej.ac.id/handle/1 23456789/79341

Syah, A. F., \& Efendy, M. (2011). Studi Sumberdata Potensial di Wilayah Pesisir dan Lautan Kabupaten Sumenep . Jurnal Ilmiah Perikanan dan Kelautan Vol. 3 No. 2, 236-237.

Thontowi, J. (2009). Kewenangan Daerah Dalam Melaksanakan Hubungan Luar Negeri (Studi Kasus di Propinsi Jawa Barat dan DIY) . JURNAL HUKUM NO. 2 VOL, 150.

Timur, B. P. (2018). Retrieved from http://bappeda.jatimprov.go.id/

Wulansari, S. (1990). Kepentingan Indonesia dalam Kerjasama Sister City Jakarta- Beijing di Bidang Pariwisata. eJournal Ilmu Hubungan Internasional, Volume 5, Nomor 4, 1273-1286. 